\title{
JURNAL ILMU KEPERAWATAN \\ (Journal of Nursing Science)
}

\author{
Volume 6 No. 1, Mei 2018
}

\section{SUSUNAN REDAKSI JURNAL ILMU KEPERAWATAN}

\section{Editor Kepala}

Ns. Bintari Ratih K, M.Kep

\section{Penyunting/Editor}

Ns. Tina Handayani, M.Kep

\section{Desain Grafis}

Ns. Ahmad Hasyim W., M.Kep, MN

\section{Sekretariat}

Ns. Annisa Wuri Kartika., M.Kep

\section{Alamat Redaksi}

Gedung Biomedik Lt. 2

Fakultas Kedokteran Universitas Brawijaya

Jalan Veteran Malang 65145

Telepon (0341) 551611, 569117, 567192

Pesawat 126;

Fax (62) (0341) 564755

Email: jik@ub.ac.id

Website: www.jik.ub.ac.id

\section{DAFTAR ISI}

THE EXPERIENCE OF SHADOW TEACHERS IN HELPING CHILDREN WTH SPECIAL NEEDS IN TELOGO PATUT ELEMENTARY SCHOOL I GRESIK

Abd. Nasir, Indah Winarni, Retno lestari........

NURSES EXPERIENCE IN IMPLEMENTING A TRIAGE ON MASS VISITATION IN THE EMERGENCY DEPARTMENT OF NGANJUK DISTRICT HOSPITAL TYPE B

Agus Khoirul Fuadi, Retty Ratnawati, Tony Suharsono. $10-21$

QUALITY OF LIFE AND MENTAL EMOTIONAL HEALTH OF ELDERLY PEOPLE

Alfrina Hany.. $22-28$

PHENOMENOLOGY STUDY: CAREGIVER EXPERIENCE IN NURSING ELDERLY WITH SELF-CARE DEFICIT AT PANTI WERDHA PANTI PANGESTI LAWANG

Ellia Ariesti, Retty Ratnawati, Retno Lestari.....

$.29-42$

DIFFERENCES EFFECT OF PROGRESSIVE MUSCLE RELAXATION THERAPY AND SUPPORTIVE THERAPY ON PARENTS ANXIETY WITH CHILDREN HOSPITALIZATION AT RSUD DR. R. SOEDJONO SELONG EAST LOMBOK

Farida Maemunah M., Retty Ratnawaty, Asti Melani A..... $43-54$

ANALYSIS OF FACTORS AFFECTING THE APPLICATION OF AUSTRALASIAN TRIAGE SCALE (ATS) IN EMERGENCY DEPARTEMENT NGUDI WALUYO WLINGI HOSPITAL

Mohammad Nur F., Setyowati Soeharto, Dewi Kartikawati N. $.55-66$

THE EXPERIENCE OF TEMS NURSES IN HANDLING TRAFFIC ACCIDENT VICTIMS IN RSUD DR. ISKAK TULUNGAGUNG

Maria Wisnu Kanita, Retty Ratnawati, Retno Lestari. $67-78$

THE DIFFERENCES OF CORRELATIONOF THE TIMI, GRACE, AND KILLIP RISK SCORES AS PREDICTOR PROGNOSIS PATIENTS WITH NON ST-ELEVATION MYOCARD INFARCTION ACUTE CORONARY SYNDROME IN ICCU RSUD DR. ISKAK TULUNGAGUNG

Rina Anggraini I.S, Titin Andri Wihastuti, Dewi Kartikawati N.. $79-87$

WORKLOAD RELATION BASED ON WORKLOAD ASSESSMENT WITH THE COMPLETENESS OF NURSING CARE DOCUMENTATION BY IMPLEMENTING NURSES IN THE EMERGENCY DEPARTMENT OF RSU. ANUTAPURA PALU AND RSU. UNDATA PALU Sasnita Salam, Titin Andri Wihastuti, Tony Suharsono. $.88-95$

FAMILY SUPPORT IN IMPROVING INDEPENDENCE OF STROKE PATIENTS

Setyoadi, Tina Handayani Nasution, Amanda Kardinasari. $96-107$

FACTOR ANALYSIS RELATED TO FAMILY PREPAREDNESS FACING DISASTER IMPACT IN TERNATE CITY OF MALUKU UTARA PROVINCE

Syafrudin L. Ahmad, Ahsan, Mukhamad Fathoni. $108-123$

THE EFFECT OF HEALTH EDUCATION WITH AUDIO-VISUAL MEDIA TOWARD EXTERNAL GENITAL HYGIENE BEHAVIORS TO PREGNANT WOMEN IN PRIMARY HEALTH CARE OF MALANG WORKING AREA

Ulfa Fauziyah H., Fransiska Imavike F., Muladefi Choiriyah..

$124-135$

PATIENT'S CHEST DISCOMFORT ASSOCIATED WITH DELAY IN REPERFUSION THERAPY ACUTE CORONARY SYNDROME

Elizabeth Yun Yun V., Djanggan Sargowo, Tony Suharsono. $136-146$

RELATIONSHIP BETWEEN KNOWLEDGE, ATTITUDE, DENTAL CARE AND DENTAL CARIES IN CHILDREN

Ronasari Mahaji Putri, Susmini.

$147-156$ 
